Cosme, Ana Maria Ferreira; Da Silva, Janaína Barbosa. Cadastro Ambiental Rural: Dos preceitos, conceitos, das definiciões a promulgação da Lei 12.651/2012. GeoGraphos [En línea]. Alicante: Grupo Interdisciplinario de Estudios Críticos y de América Latina (GIECRYAL) de la Universidad de Alicante, 2 de junio de 2019, vol. 10, no 117 p. 149178 [ISSN: 2173-1276] [DL: A 371-2013] [DOI: 10.14198/GEOGRA2019.10.117].

\title{
Ge Graphos
}

\section{CADASTRO AMBIENTAL RURAL: DOS PRECEITOS, CONCEITOS, DAS DEFINIÇÕES A PROMULGAÇÃO DA LEI 12.651/2012}

\section{Ana Maria Ferreira Cosme}

Centro de Tecnologia e Recursos Naturais. Universidade Federal de Campina Grande-

UFCG (Campina Grande, Paraiba, Brasil)

ID ORCID: https://orcid.org/0000-0002-1342-1950

Correio eletrônico: gestaozte@ gmail.com

Janaína Barbosa da Silva

Universidade Federal de Campina Grande-UFCG (Campina Grande, Paraiba, Brasil)

ID ORCID: https://orcid.org/0000-0001-6366-2165

Correio eletrônico: janainasimov@yahoo.com.br

Recibido: 20 de enero de 2019. Aceptado: 02 de junio de 2019 


\title{
RESUMO
}

O objetivo geral dessa pesquisa apresenta o Cadastro Ambiental Rural brasileiro-CAR: da criação, implantação a efetivação. A metodologia de pesquisa utilizada foi exploratório-descritiva, através de artigos, relatórios, teses, dissertações e discussões recentes. Entende-se que o CAR é considerado como um dos principais instrumentos da Legislação ambiental brasileira que contribui na gestão e no monitoramento das florestas remanescentes no Território Nacional, portanto, considerado um novo instrumento de gestão pública. O CAR, em consonância com o Código Florestal, por meio da Lei 12.651/12, traz em seu escopo regras de utilização das terras; proteção das florestas e seus remanescentes. Além de orientações sobre as áreas de vegetação nativa das propriedades e posses rurais, as obrigações sobre a Reserva Legal e a Área de Preservação Permanente, que são monitoradas por meio das informações prestadas ao CAR, que tem como finalidade, apoiar Administração Pública no processo de regularização ambiental de propriedades e posses rurais do Brasil, estes dados são registrados no Sistema de Cadastro Ambiental Rural-SICAR. Contribuindo para a sua proteção, manutenção e desenvolvimento ambiental. O CAR é um instrumento de suma importância para regulação da proteção ambiental brasileiro, auxiliando o meio ambiente para que ele forneça o fomento necessário para o desenvolvimento e o bemestar humano.

Palavras-chave: Código Florestal Brasileiro, Reserva Legal, Área de Preservação Permanente, Preenchimento do SICAR.

\section{RURAL ENVIRONMENTAL REGISTRY: FROM THE PRECEPTS, CONCEPTS, FROM THE DEFINITIONS TO THE PROMULGATION OF THE LAW 12,651 / 2012}

\begin{abstract}
The general objective of this research is the Brazilian Rural Environmental CadastreCAR: from the creation, implementation and implementation. The research methodology used was exploratory-descriptive, through articles, reports, theses, dissertations and recent discussions. It is understood that the CAR is considered as one of the main instruments of the Brazilian Environmental Legislation that contributes to the management and monitoring of the remaining forests in the National Territory, therefore, considered a new instrument of public management. The CAR, in accordance with the Forest Code, through Law 12.651 / 12, brings in its scope rules of land use; protection of forests and their remnants. In addition to guidelines on the native vegetation areas of rural properties and possessions, the obligations on the Legal Reserve and the Permanent Preservation Area, which are monitored through information provided to the CAR, whose purpose is to support Public Administration in the process of environmental regularization of rural properties and possessions in Brazil, these data are recorded in the Rural Environmental Cadastre System-SICAR. Contributing to its protection, maintenance and environmental development. CAR is an extremely important instrument for regulating Brazilian environmental protection, helping the environment to provide the necessary support for human development and well-being.
\end{abstract}


Keyword: Brazilian Forest Code, Legal Reserve, Permanent Preservation Area, Completion of SICAR.

\section{REGISTRO AMBIENTAL RURAL: DE LOS PRECEPTOS, CONCEPTOS, DE LAS DEFINICIONES LA PROMULGACIÓN DE LA LEY 12.651 / 2012}

\section{RESUMEN}

El objetivo general de esta investigación presenta el Catastro Ambiental Rural brasileño-CAR: de la creación, implantación a la efectuación. La metodología de investigación utilizada fue exploratoria-descriptiva, a través de artículos, informes, tesis, disertaciones y discusiones recientes. Se entiende que el CAR es considerado como uno de los principales instrumentos de la Legislación ambiental brasileña que contribuye en la gestión y el monitoreo de los bosques remanentes en el Territorio Nacional, por lo tanto, considerado un nuevo instrumento de gestión pública. El CAR, en consonancia con el Código Forestal, por medio de la Ley 12.651 / 12, trae en su ámbito reglas de utilización de las tierras; protección de los bosques y sus remanentes. Además de orientaciones sobre las áreas de vegetación nativa de las propiedades y posesiones rurales, las obligaciones sobre la Reserva Legal y el Área de Preservación Permanente, que son monitoreadas por medio de las informaciones prestadas al CAR, que tiene como finalidad, apoyar Administración Pública en el proceso de la regularización ambiental de propiedades y posesiones rurales de Brasil, estos datos se registran en el Sistema de Registro Ambiental Rural-SICAR. Contribuyendo a su protección, mantenimiento y desarrollo ambiental. El CAR es un instrumento de suma importancia para la regulación de la protección ambiental brasileña, ayudando al medio ambiente para que proporcione el fomento necesario para el desarrollo y el bienestar humano.

Palabras clave: Código Forestal Brasileño, Reserva Legal, Área de Preservación Permanente, Relleno del SICAR.

\section{INTRODUÇÃO}

O que motivou a realização desta pesquisa foi à inquietação, em compreender a conjuntura dos acontecimentos ocorridos nas propriedades rurais do Brasil, especificamente o que tange a preservação dos remanescentes de vegetações naturais ainda existentes nessas propriedades. Entende-se que o uso e a exploração da terra no Brasil caracterizam-se por políticas governamentais imediatistas e voltadas para atender aos interesses das forças que comandam o processo econômico brasileiro.

Para compreender a formação das propriedades agrícolas precisamos entender que "a agricultura cobre aproximadamente metade da área habitável da Terra" (Loch, 2015, p. 172). E que as decisões executadas pelos agricultores na gestão de seus territórios, são importantes para todos. Historicamente, as atividades agrícolas contribuem com a produção de alimentos e criação de animais, e devem colaborar com a preservação de recursos naturais visando garantir a segurança alimentar da população. 
No Brasil para o pequeno produtor, a estrutura fundiária é fortemente concentradora, com diversos proprietários de terras e uma grande complexidade de problemas como: falta de políticas governamentais à produção e ao acesso a terra; ausência de um marco jurídico que proteja as terras dos beneficiários; êxodo rural; desastres naturais, vulnerabilidade ecológica; infertilidade das terras e redução das áreas florestadas. Estes problemas são reflexos da construção histórica da formação da propriedade privada. E estes não correspondem à finalidade das Políticas públicas que estão voltadas para o desenvolvimento rural, "no qual devem considerar o progresso material; o respeito às capacidades e anseios das pessoas; a conservação dos recursos naturais e os benefícios que recebem ao preservar os ecossistemas" (Silva, 2008).

Atualmente no Brasil existe uma serie de Decretos, Normas e Leis que auxiliam na gestão do desenvolvimento rural e ambiental. Pois, não podemos discutir as questões rurais sem envolver assuntos de ordem ambiental, sendo estes indissociáveis no quesito preservação dos recursos naturais.

Destaca-se para este pesquisa a Lei 12.651 de maio de 2012, que versa sobre a proteção da vegetação nativa, sendo mais conhecida como "novo" Código Florestal Brasileiro (CodFlo). Esta Lei trás em seu escopo, Capítulo VI, o Cadastro Ambiental Rural (CAR), onde o artigo 29 da Lei, afirma que: É criado o CAR, no âmbito do Sistema Nacional de Informação sobre Meio Ambiente - SINIMA, registro público eletrônico de âmbito nacional, obrigatório para todos os imóveis rurais, com a finalidade de integrar as informações ambientais das propriedades e posses rurais, compondo base de dados para controle, monitoramento, planejamento ambiental, econômico e combate ao desmatamento (Brasil, 2012).

Essa definição é a base para esta pesquisa, que tem como objetivo o Cadastro Ambiental Rural (CAR) brasileiro: da criação, implantação a efetivação. Trata-se de um tema rente com poucas publicações sobre o referido assunto, isso nos despertou o interesse pela ampla discussão e aplicação do CAR na área ambiental nacional.

\section{MATERIAIS E MÉTODO}

Optou-se por uma pesquisa exploratório-descritiva, com caráter histórico através de artigos, relatórios, teses, dissertações, estudos ambientais, e pesquisa em sites e documentos de órgãos governamentais tanto para as definições e contextualizações, assim:

\footnotetext{
Esta pesquisa tem como objetivo proporcionar maior familiaridade com o problema, com vistas a torna-lo mais explicito ou constituir hipóteses. Pode-se dizer que estas pesquisas têm o objetivo principal o aprimoramento de ideias ou a descoberta de intuições. Seu planejamento é, portanto, bastante flexível, de modo que possibilite a consideração dos mais variados aspectos relativos ao fato estudado (Gil, 2008, p. 41).
}

A pesquisa exploratória é usada em casos nos quais é necessário definir o problema com maior precisão e identificar cursos relevantes de ação ou obter dados adicionais antes que se possa desenvolver uma abordagem (Vieira, 2002 p. 65). 
Os preceitos, conceitos e definições acerca da evolução das propriedades de terras, no qual, buscaram-se informações que nós fornecêssemos bases e subsídios norteadores, por meio de levantamentos históricos da divisão e posse da terra, perpassando por questões agrárias, sistema nacional de cadastro rural e programas ambientais, até a criação da Lei 12.651 de 05 de maio de 2012, que trás em seu escopo, indicações para os proprietários e posseiros de terra, para que realizem o Cadastro Ambiental Rural o (CAR) está Lei conduzirá o desenvolvimento do respectivo estudo.

\section{DOS PRECEITOS, CONCEITOS, DAS DEFINIÇÕES A PROMULGAÇÃO DA LEI 12.651/2012}

Para melhor compreensão dos pontos discutidos ao longo da pesquisa, construiu-se um breve organograma, que demonstra a evolução Histórica dos Registros e Cadastros de Imóveis Rurais no Brasil até a efetivação do Cadastro Ambiental Rural- CAR (Figura 1). Este servirá como guia, para compreendermos quais as Leis, Normas, Decretos e Códigos que subsidiaram a criação do CAR.

\section{Divisão Do Território Nacional E A Lei De Terras}

Quando da análise cronológica dos registros e cadastros de imóveis é possível observar Leis, Decretos, Códigos e programas, que contribuíram e contribuem de forma direta ou indireta, para a criação e efetivação da Lei 12.651/2012.

Anterior à ocupação do território hoje brasileiro, a Coroa Portuguesa juntamente a com a espanhola, firmaram o acordo em relação à divisão desse espaço. E por meio desta ação foram implantadas as Capitanias Hereditárias, sistema adotado em muitas colônias portuguesas, baseado no princípio de privatização da propriedade (Loch e Erba, 2007).

As capitanias foram separadas em sistema de Sesmarias. Esse era uma concessão de terras, ofertada aos imigrantes que tivessem o interesse de instalar-se nas terras de propriedade da Coroa Portuguesa para explora-las e desenvolve-las. Entende-se que:

O sesmeiro recebia a terra como se fosse sua e tinha o poder político e econômico sobre ela. Para que o colono pudesse obter o direito de se tornar um sesmeiro, tinha que se dispor a plantar e fixar-se na terra (ocupar e explorar) efetivamente e defende-la do estrangeiro (Pozzatti, 2017). 


\section{Figura 1. Organograma que demonstra a evolução Histórica dos Registros e Cadastros de Imóveis rurais}

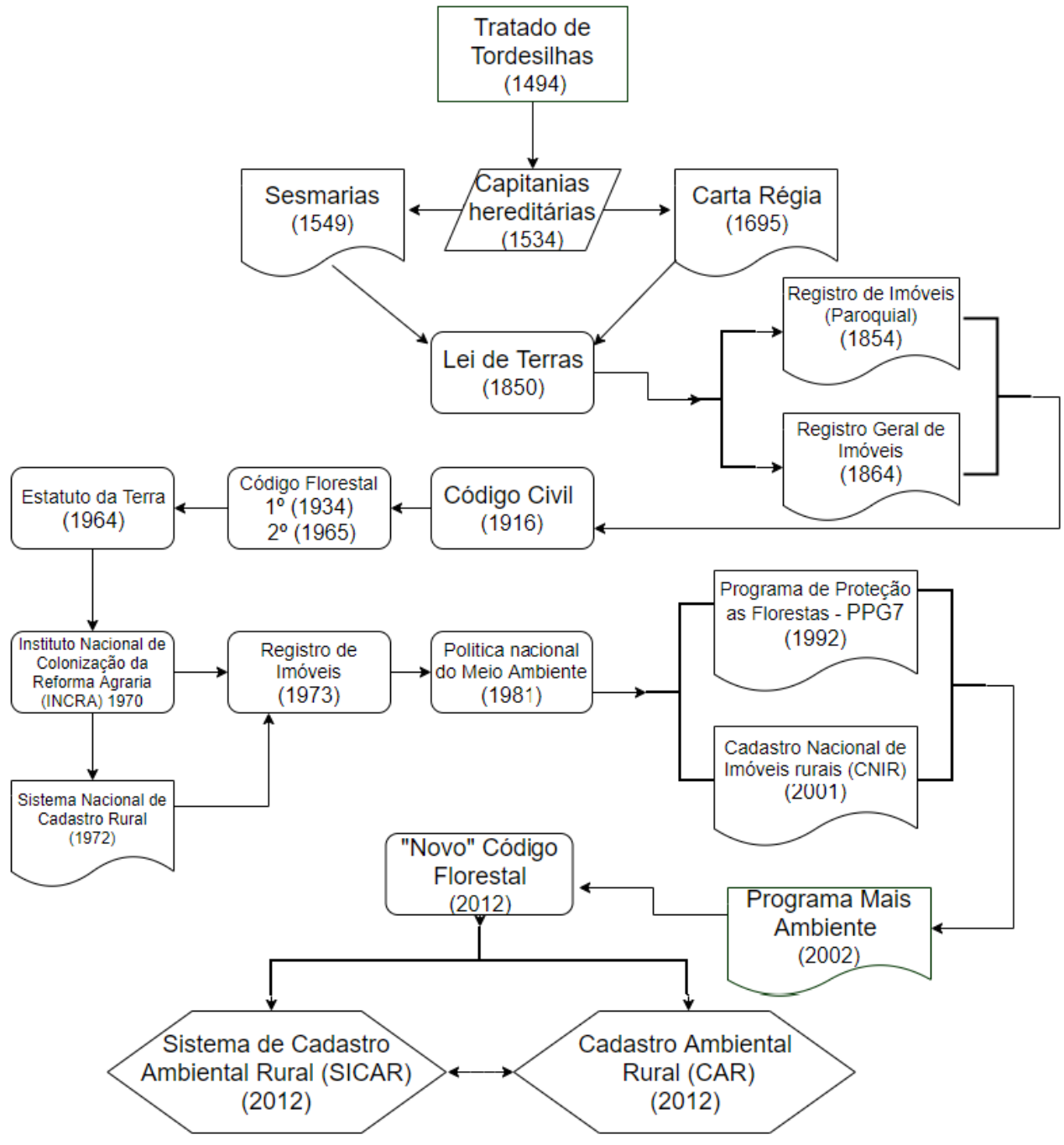

Fonte: Autores.

A sesmaria vigorou até meados de 1822, obedecendo às ordens referentes à apropriação de terras, grande parte das sesmarias deram origem aos grandes latifúndios em sua maioria improdutiva. Esta improdutividade favoreceu o surgimento dos chamados posseiros ${ }^{1}$, esses não possuíam a propriedade das terras por eles ocupadas, com a chegada dos colonos, os posseiros eram obrigados a desocupar as terras, passando a assumir o papel de foreiro ${ }^{2}$, indo a ocupar outras terras mais distantes.

Com o aumento considerado dos foreiros, a Coroa Portuguesa buscava formas para realizar a cobrança de pagamento do foro. Conforme A. Carneiro (2003, p. 68), no ano de 1695, a metrópole instituía a obrigação de pagamento de foro, numa tentativa de aumentar o seu controle sobre a situação da apropriação territorial na colônia, ação que

\footnotetext{
${ }^{1}$ De acordo com L. Souza (2017), Posseiro é o lavrador que trabalha na terra sem possuir nenhum título legal, nenhum documento reconhecido legalmente ou registrado em cartório que defina como proprietário sendo classificado como ocupante da terra, nos censos oficiais, ou como posseiro na linguagem comum.

${ }^{2}$ Segundo A. Ferreira (2010), Foreiro é quem paga foro; tributário, obrigado, sujeito, exposto.
} 
na época era inviável, por não saberem ao certo a localização e o tamanho das terras concedidas.

Após a implementação da Lei de Terras $n^{\circ} 601$ de setembro de 1850 , houve a criação de uma divisão geral de terras públicas, que obrigava todos os proprietários com títulos de propriedade ${ }^{3}$ ou posse $e^{4}$ a registrar suas terras, visando garantir os seus direitos sobre essas. Segundo Diniz:

Primeira Lei de terras que veio dar um grande passo, discriminando os bens de domínio público dos particulares [...], criando o registro paroquial de terras possuídas no império, que visava inventariar as posses existentes em todas as províncias brasileiras. Os proprietários rurais, sob severa pena, eram obrigados a registrar suas terras (Diniz, 2012. p. 113)

A Lei de Terras considera crimes puníveis com prisão, "de dois a seis meses, e multa, para quem causar desmatamento e realizar queimada. Além disso, ainda estabeleceu a responsabilidade por dano ambiental fora do âmbito da legislação civil. Além de sanções penais o infrator submetia-se a sanções civis e administrativas" (Milaré, 2011).

\section{Estatuto Da Terra}

Posteriormente, em 1854 foi criado o Decreto $\mathrm{n}^{\mathrm{o}} 1.318 / 54$, que definia a regulamento das atribuições e as competências da repartição geral das terras públicas, esse criado pela Lei de Terras de 1850 , onde era realizada a divisão das áreas destinadas à colonização de indígenas e estrangeiros (Carneiro, 2003, p.72).

Diante do exposto e a partir de algumas análises das formulações jurídicas, com a transição do Brasil Colônia para o Império, surgiram novas leis e decretos que contemplavam os assuntos de ordem ambiental. Neste ponto pode-se adentrar nas questões ambientais, que norteiam a pesquisa. Verificou-se que houve a inclusão de termos como: Florestas protetoras, que foi citada a princípio no Decreto 23.793/ 1934, definida em seu artigo $4^{\mathrm{o}}$ : "Serão consideradas florestas protetoras as que, por sua localização, servirem conjunta ou separadamente para qualquer dos fins" (Brasil, 1934), destaca-se que no respectivo Decreto não se delimitava o distanciamento das nascentes e/ou mananciais hídricos.

Outro exemplo foi à inclusão do termo Áreas de Preservação Permanente (APP), promulgado pelo primeiro Código Florestal Brasileiro, mediante a Lei 4.771/1965, que estabeleceu em seu artigo $2^{\circ}$, "Consideram-se de preservação permanente, pelo efeito desta Lei, as florestas e demais formas de vegetação natural”, esta definição assume um papel sine qua non, tornando-se norteadora para as decisões a serem executadas na forma da Lei.

Com o advento do Estatuto da Terra em 1964 por meio da Lei 4.504/ 64 trás no artigo $1^{\mathrm{o}}$ que, "Esta Lei regula os direitos e obrigações concernentes aos bens imóveis rurais,

\footnotetext{
3 Tratada como um direito fundamental, um princípio diretamente conectado aos interesses sociais e valores econômicos, (Pires, 2005).

${ }^{4}$ Segundo T. Zavascki (2005). Sistema jurídico brasileiro pressupõe superar a noção, ainda corrente, de que ela representa, simplesmente, a exteriorização do direito de propriedade.
} 
para os fins de execução da Reforma Agrária e promoção da Política Agrícola”. E cria também os Instituto Brasileiro de Reforma Agrária (IBRA) e o Instituto Nacional de Desenvolvimento Agrário (Inda), em 1970 ouve uma fusão destes dois institutos, criado o Instituto Nacional de Colonização da Reforma Agraria (INCRA), dentre várias diretrizes destacamos a primeira, que afirma:

O INCRA implementará a reforma agrária promovendo a democratização do acesso a terra através da criação e implantação de assentamentos rurais sustentáveis, da regularização fundiária de terras públicas e gerenciará a estrutura fundiária do país, contribuindo para o desenvolvimento sustentável, para a desconcentração da estrutura fundiária, para a redução da violência e da pobreza no campo e promoção de igualdade (INCRA, 2017).

Contudo, considerando o desenvolvimento dos poderes públicos, criou-se em 1972 o Sistema Nacional de Cadastro Rural (SNCR), por meio da Lei 5.868/72, esse traz em seu escopo, cadastros que devem ser preenchidos por proprietários, detentores, arrendatários e parceiro rurais, além dos cadastros de terras e o cadastro nacional de florestas públicas. Para A. Laskos, et al (2016) o SNCR "tem por objetivo dar segurança jurídica aos proprietários de imóveis, garantindo acesso a políticas públicas, e possibilitar o planejamento do uso e ocupação da terra, além do monitoramento da legislação ambiental brasileira". Ainda sobre a luz do Estatuto da Terra e de outras leis supracitadas, foi promulgada com a intenção de instituir o registro de imóveis ${ }^{5}$ por intermédio da Lei 6.015/1973 a Lei de Registros Públicos. Essas subsidiaram a criação de novos preceitos, como da Politica Nacional do Meio Ambiente (Lei 6.938 de 1981) e o atual Código Civil 10.406 de 10 de janeiro de 2002.

\section{Lei 12.651 de 25 de Maio de 2012}

Entende-se que a efetivação do Código Florestal Brasileiro de 2012, regulamentou a utilização das florestas, considerando a biodiversidade e seus recursos, possibilitando a criação e as alterações de novas leis ambientais, com isso intensifica-se a Política Florestal Brasileira. Neste contexto vale salientar a implantação de programas que vieram a corroborar com a conservação de áreas florestais, como o Programa Piloto do Grupo dos G7 (PPG7), e na escala Brasil denominado de Preservação das Florestas Tropicais do Brasil. Segundo o Ministério do Meio Ambiente (MMA).

O PPG7 é uma iniciativa do governo brasileiro em parceira com a comunidade internacional. Está sendo considerado um dos maiores programas de cooperação multilateral relacionado a uma temática ambiental de importância global. Foi financiado pelos governos dos países do G7, Países Baixos e União Europeia (MMA 2009).

O PPG7, formulado em 1992, com o objetivo de "maximizar os benefícios ambientais das florestas tropicais de forma consistente com as metas de desenvolvimento do Brasil, por meio da implantação de uma metodologia de desenvolvimento sustentável que contribuirá com a redução contínua do índice de desmatamento" (MMA, 2017a). O respectivo programa foi efetivado em 1994 e demostrou seus primeiros resultados

\footnotetext{
${ }^{5}$ É a obtenção da aquisição da propriedade inter vivos, pois o contrato, a titulo oneroso ou gratuito, assim sendo, somente a intervenção estatal, realizada pelo oficial do cartório imobiliário, conferira direitos reais, a partir da data em que se fizer assentado do imóvel (Diniz, 2012).
} 
alcançados, por seus subprogramas e projetos, a exemplo dos Subprogramas de Políticas e Recursos Naturais (SPRN), que tinha como foco estruturar e consolidar os órgãos estaduais de Meio Ambiente da Amazônia Legal, para que este programa em sua primeira fase ampliasse a capacidade do Ministério do Meio Ambiente para atuar na região amazônica (MMA, 2017a).

Em sua segunda fase o PPG7, buscou preencher as lacunas de sua fase anterior, por meio da gestão pública e comunitária de áreas protegidas (unidades de conservação e terras indígenas); uso sustentável dos recursos naturais; monitoramento, prevenção e controle de desmatamentos e queimadas; desenvolvimento local e regional; e ciência e tecnologia para o desenvolvimento sustentável (MMA, 2017a).

Este programa serviu de base para a implantação do Sistema de Licenciamento Ambiental de Propriedades Rurais (SLAPR), em 1997, especificamente no estado de Mato Grosso. Considerando que:

O Mato Grosso instituiu o Sistema de Licenciamento ambiental em Propriedades Rurais (SLAPR) através do Decreto Estadual $\mathrm{n}^{\circ}$ $1.401 / 2009$, tendo em vista que, historicamente, o Estado possui elevados percentuais de desmatamento na área da Amazônia Legal, o que refletia na preocupação em se estabelecer mecanismos para a alteração deste cenário (Fonseca e Silva, 2015).

Vele salientar que este Decreto não assegura o domínio ou a posse da propriedade nesta região, apresentando-se apenas como um instrumento auto declaratório, para fins de monitoramento.

Em 2009, o MMA, cria o Programa Mais Ambiente pelo Decreto 7.029/2009, visando inserir um Cadastro Ambiental Rural em nível federal. Esses decretos e Leis culminaram na formulação na Lei de $\mathrm{n}^{\circ}$ 12.651, publicada no Diário Oficial da União em 25 de Maio de 2012, conhecida como "Novo" Código Florestal. Essas transformações despertaram a preocupação da proteção ambiental, especialmente pela questão do desmatamento, devemos entender que as Leis são instrumentos de conduta para a sociedade, visando à manutenção de um meio ambiente equilibrado.

O Código Florestal de 2012 se consolidou em meio há diversas discussões, principalmente entre ambientalistas e ruralistas, visando à inserção de mecanismos inovadores para o aumento de ações ambientais, com a intenção de ampliar a consciência protecionista, aliada ao desenvolvimento econômico, busca incentivar a conservação e a recomposição da vegetação.

O Código Florestal apresenta algumas recomendações, como a implantação do Cadastro Ambiental Rural, Reserva Legal e mudanças nas áreas de preservação dos imóveis rurais, conforme o seu artigo $1^{\circ}$ :

Esta Lei estabelece normas gerais sobre a proteção da vegetação, áreas de Preservação Permanente e as áreas de Reserva Legal; a exploração florestal, o suprimento de matéria-prima florestal, o controle da origem dos produtos florestais e o controle e prevenção dos incêndios florestais, e prevê instrumentos econômicos e financeiros para o alcance de seus objetivos (Brasil, 2012a). 
Diante da definição deste artigo, D. Silva (2015, p.41), afirma:

Referentes à proteção ambiental, como a margem mínima de preservação de áreas por regiões, trazidos pelo Código Florestal, ele não foi de plano atendido, vez que, apesar de trazer as Áreas de Preservação Permanente (APP) e de Reserva Legal (RL) informando a imprescindibilidade em sua proteção, os limites traçados não sustentaram o controle do desmatamento, demonstrando a ausência de efetividade.

Estes fatos geraram e ainda geram diversas discussões, entre os atores sociais envolvidos. Principalmente no entendimento de alguns ambientalistas, que existem inconstitucionalidades na formulação dessa Lei. Mas, diante de algumas questões, devese, defender a possibilidade de "ganhar com a floresta em pé, ou seja, valorizar a preservação florestal” (Silva, 2015, p.42).

As inconstitucionalidades estão relacionadas à Reserva Legal, no qual em seu artigo 68 da Lei 12.651/12, afirma que:

Os proprietários ou possuidores de imóveis rurais que realizaram supressão de vegetação nativa respeitando os percentuais de Reserva Legal previstos pela legislação em vigor à época em que ocorreu a supressão são dispensados de promover a recomposição, compensação ou regeneração para os percentuais exigidos nesta Lei (Brasil, 2012a).

Isso demonstra que antes da criação dessa Lei, os proprietários ou posseiros de terras que haviam realizado modificações, em áreas que hoje seriam destinadas a RL, estão desobrigados de realizar a recomposição das áreas degradadas, destaca-se também a isenção dos pagamentos de multas aplicadas aos proprietários que desmataram as APPs (Laureano e Magalhães, 2011). Evidenciamos também a intervenção nas Áreas de Preservação Permanente, ao observamos o artigo $8^{\circ}$, inciso $2^{\circ}$ :

A intervenção ou a supressão de vegetação nativa em Área de Preservação Permanente de que tratam os incisos VI e VII do caput do art. $4^{\circ}$ poderá ser autorizada, excepcionalmente, em locais onde a função ecológica do manguezal esteja comprometida, para execução de obras habitacionais e de urbanização, inseridas em projetos de regularização fundiária de interesse social, em áreas urbanas consolidadas ocupadas por população de baixa renda (Brasil 2012a).

Diante do exposto, observa-se que há lacunas na referida Lei que favorecem ações de degradação sobre as APP'S e RL's, que afetam direta ou indiretamente a sua estrutura arbórea. Ressaltam-se também as inconstitucionalidades impostas pelo Decreto 7.830 de 17 de outubro de 2012, que dispõe sobre o Sistema de Cadastro Ambiental Rural (CAR), esse estabelece normas de caráter geral aos Programas de Regularização Ambiental, de que trata a Lei no 12.651, de 25 de maio de 2012, e dá outras providências.

Diante disso destaca-se o Art. 18 do Decreto 7.830/2012, Parágrafo único: "O proprietário ou possuidor de imóvel rural que optar por recompor a RL com utilização do plantio intercalado de espécies exóticas terá direito a sua exploração econômica" (Brasil, 2012b). Com isso observa-se que alguns latifundiários encontram nestas lacunas 
formas de burlar o Código Florestal, entretanto para realizar a manutenção das florestas é preciso a sua aplicação, independentemente das lacunas encontradas em seu escopo.

Nesta situação, entende-se que o proprietário realiza a recomposição, mas posteriormente ele pode utilizar o que foi plantado para obter lucro, e novamente voltar a desmatar e a reflorestar inúmeras vezes, mascarado como uma ação de preservação e quiçá permanente. Percebe-se aqui uma significativa fragilidade na legislação vigente.

Contudo, na Lei 12.651/12 há alguns instrumentos que reforçam a manutenção e a preservação dos recursos, existentes no interior das propriedades, com isso buscando-se encontrar algumas alternativas para mitigar as lacunas encontradas na Lei anterior (4.771/1965). Um exemplo é o artigo $3^{\circ}$ inciso II, “APP: área protegida, coberta ou não por vegetação nativa, com a função ambiental de preservar os recursos hídricos, a paisagem, a estabilidade geológica e a biodiversidade, facilitar o fluxo gênico de fauna e flora, proteger o solo e assegurar o bem-estar das populações humanas".

A utilização de área de APP é permitida em determinados casos que visam à recomposição da mesma, no qual aceitam que as comunidades tradicionais como: indígenas, quilombolas e pescadores ribeirinhos possam realizar práticas como o sistema agroflorestal ${ }^{6}$, onde "é permitido o plantio intercalado de espécies lenhosas, perenes ou de ciclo longo, exóticas com nativas de ocorrência regional, em até $50 \%$ da área total a ser recomposta" (Empresa Brasileira de Pesquisa Agropecuária- EMBRAPA 2017).

Compreende-se que a exploração de recursos florestais de forma sustentável geralmente ocorre quando o órgão ambiental concede a autorização. Ademais a Lei mantém as atividades nas áreas já consolidadas. Contudo, as APP's, devem ser protegidas tanto no RURAL quanto URBANO, haja a vista que no contexto da formação das cidades brasileiras, há uma quantidade significativa de municípios que possuem em sua área urbana APP's, como é o caso das cidades como a de João Pessoa. Essa possui em sua malha urbana, a APP da Mata do Buraquinho com 515 hectares, e a cidade do Recife com a APP do rio Capibaribe que corta boa parte da sua região metropolitana.

A Reserva Legal é um dos instrumentos do Código Florestal relevante para a conservação e manutenção da biodiversidade, no interior da propriedade rural. $\mathrm{Na}$ prática, este instrumento favorece o processo de recuperação de APP's, proporcionando o desenvolvimento e a "resiliência" da fauna e da flora nativa. Observamos na Lei, que a RL, apresenta proporções diferenciadas, dentro do território Brasileiro. Para isso é preciso considerar:

Reserva Florestal Legal é uma limitação inerente ao atendimento da função social no exercício do direito da propriedade rural, reconhecida pela Carta Constitucional de 1988, independente da vegetação ali existente (natural, primitiva, regenerada ou plantada) ou do fato de essa vegetação ter sido substituída por outro uso do solo (Milaré, 2011).

\footnotetext{
${ }^{6}$ Sistema de uso e ocupação do solo em que plantas lenhosas perenes são manejadas em associação com plantas herbáceas, arbustivas, arbóreas, culturas agrícolas, forrageiras em uma mesma unidade de manejo, de acordo com arranjo espacial e temporal, com alta diversidade de espécies (EMBRAPA, 2017).
} 
Perante as palavras de Milaré, a RL é dividida em Amazônia Legal e Demais Regiões, onde para cada uma é atribuído um percentual de reserva a ser mantido nas propriedades, nessas áreas o uso é restrito, autorizado pelo órgão ambiental, no qual o seu tamanho varia de acordo com a Região, bioma e extensão da propriedade. Na a Amazônia Legal, (Florestas 80\%, Cerrado 35\% e Campos Gerais 20\%), para as Demais Regiões do País, são obrigadas a reservar apenas $20 \%$, salvo algumas premissas, que dependem do Zoneamento Ecológico Econômico (ZEE) e do tamanho da APP de rio varia de acordo com a largura desse dentro do imóvel rural (Figura 2).

\section{Figura 2. Faixas de áreas conforme a sua tipologia.}
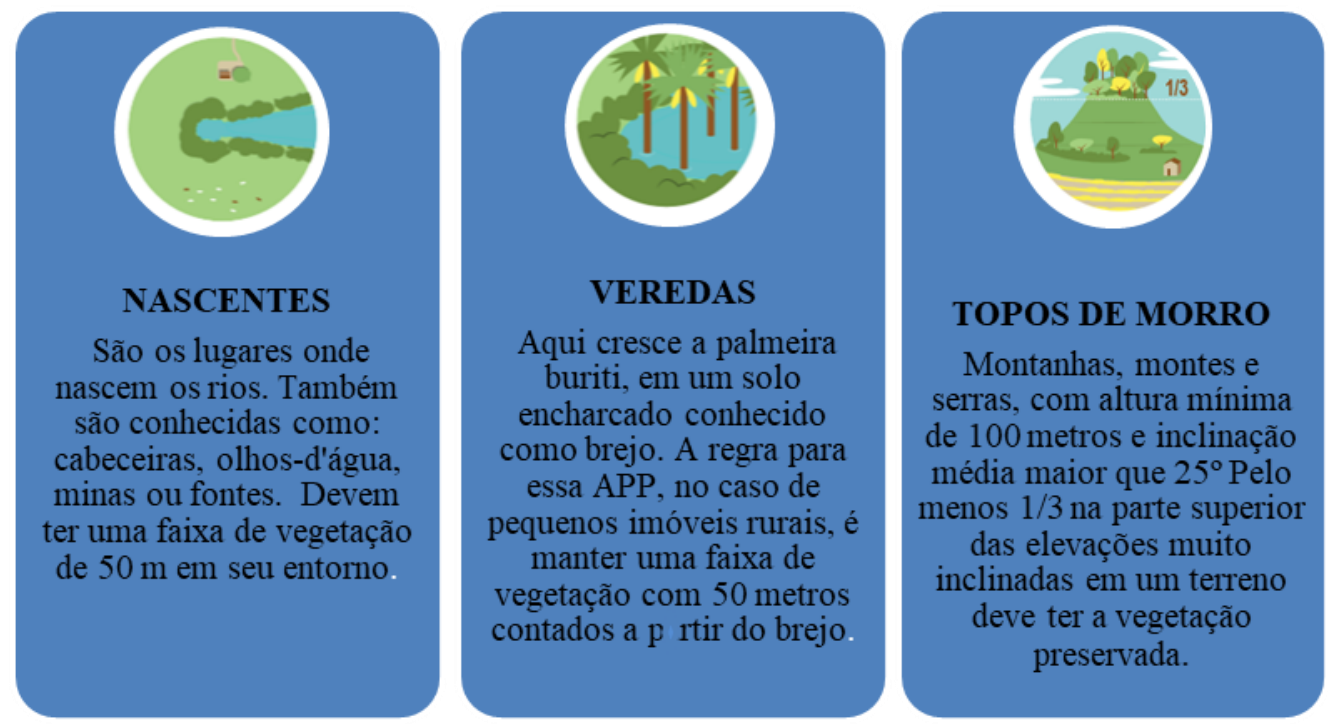

Fonte: MMA, adaptado da cartilha do CAR, produzida pelo Serviço Florestal Brasileiro, 2016a.

A RL "garante" a manutenção da diversidade das espécies, além de adotar medidas que auxiliam nos processos ecológicos e na conservação da biodiversidade existentes nos imóveis rurais. Com isso, há necessidade de respeitar as delimitações das áreas próximas aos cursos d'água, impostas pela Lei (Figura 3), que descreve a largura da vegetação a ser mantida em pequenas propriedades, entorno do espelho d'água conforme cada tipologia, com o propósito de assegurar preservação e a conservação das áreas de APP e dos mananciais hídricos.

Verifica-se na (Figura 3), que à medida que aumenta a largura do rio, aumenta a área da APP, lembrando que antes da Lei 12.651/2012 ser sancionada, boa parte das Matas ciliares havia sido destruída ou descaracterizada, por meio de inserção de culturas, em substituição da vegetação autóctone. 


\section{Figura 3. Distâncias das áreas de APP, conforme a largura do Curso d'água}

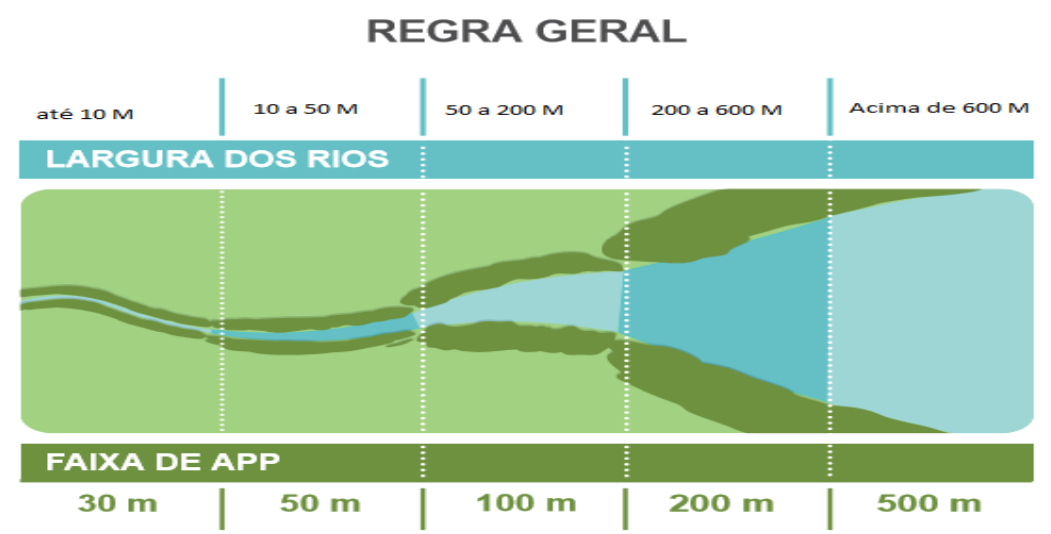

Fonte: MMA, Cartilha do CAR, produzido pelo Serviço Florestal Brasileiro, $2016 \mathrm{a}$.

\section{CADASTRO AMBIENTAL RURAL E SISTEMA NACIONAL DE CADASTRO AMBIENTAL RURAL}

Á luz do Código Florestal, há novas regras que compactuam com o Artigo 225 do Constituição Federal de 1988, para a implementação do direito ao meio ambiente ecologicamente equilibrado, para isso, em seu escopo contém alguns instrumentos de caráter informativo, como o Cadastro Ambiental Rural (CAR).

Verificou-se que o CAR é o aprimoramento do Sistema de Licenciamento Ambiental das Propriedades Rurais (SLAPR) inicialmente desenvolvido pelo Estado de Mato Grosso, por meio de sua Secretaria Estadual de Meio Ambiente. O SLAPR foi pressionado por parte do sistema econômico globalizado, além das diversas "criticas ambientais ao modelo de uso e ocupação do solo em áreas de florestas tropicais" (Azevedo, 2014).

O CAR é um instrumento, alvo de inúmeras discussões, principalmente no que se refere a Reserva Legal e a necessidade de realizar ou não a dispensa da averbação ${ }^{7}$ nos registro de matrícula de imóveis. Consideramos que a definição do CAR é:

Um registro público eletrônico, obrigatório para todos os imóveis rurais, que tem por finalidade integrar as informações ambientais referentes à situação das áreas de preservação permanente (APP), das áreas de reserva legal, das florestas e dos remanescentes de vegetação nativa, das áreas de uso restrito e das áreas consolidadas das propriedades e posses rurais do país (Brasil, 2012 a; Banco Nacional do Desenvolvimento- BNDES, 2017).

\footnotetext{
${ }^{7}$ Segundo J. Queiroz (2011), Averbar significa registrar no Cartório de Registro de imóveis a área que está sendo demarcada para que seja a Reserva Florestal Legal, e a partir da sua averbação essa área não pode sofrer modificações artificiais, somente por força da natureza, excluídas as hipóteses previstas de manejo e compensação no Código Florestal.
} 
O Cadastro tonou-se obrigatório por meio da Lei $\mathrm{n}^{\mathrm{o}} 12.651$ de 25 maio de 2012, no âmbito do Sistema Nacional de Informações sobre Meio Ambiente (SINIMA), com proposito de associar informações ambientais prestadas pelos agricultores, proprietários e posseiros. Em 2014 passou a ser regulamentado por uma Instrução Normativa do Ministério do Meio Ambiente de $\mathrm{n}^{\mathrm{o}} 2$, com isso deu-se inicio a geração de um novo panorama das propriedades rurais brasileiras. Ressaltamos que de 2012 até 2018 o CAR tem prorrogando o prazo de inscrição no cadastro, recentemente o presidente da República anunciou o Decreto $\mathrm{n}^{\circ}$ 9.257, de 29 de dezembro de 2017, que prorroga até o dia 31 de maio de 2018, em virtude de algumas regiões não terem atingido a meta dos cadastros estipulados pelo Governo Federal, desta forma encontram-se em processo de cadastramento.

Conforme o MMA (2016b) a inscrição no CAR irá auxiliar no planejamento ambiental e econômico do uso e ocupação do imóvel rural, sendo assim a primeira etapa, para obtenção da regularidade ambiental do imóvel. Com tudo entendese que a informações ambientais são de suma importância para a construção de políticas públicas de proteção ambiental e da consciência da coletividade, através do livre acesso aos dados que envolvam os imóveis rurais (Silva, 2015). Por meio das informações prestadas ao Sistema de Cadastro Ambiental Rural (SICAR). Conforme o Serviço Florestal Brasileiro, afirma que o SICAR foi criado por meio do Decreto $n^{\circ} 7.830 / 2012$ que é:

Definido como sistema eletrônico de âmbito nacional destinado à integração e ao gerenciamento de informações ambientais dos imóveis rurais de todo o País. Essas informações destinam-se a subsidiar políticas, programas, projetos e atividades de controle, monitoramento, planejamento ambiental e econômico e combate ao desmatamento ilegal, (Brasil, 2016).

A partir dos dados inseridos no SICAR, é possível realizar alguns levantamentos quantitativos de áreas de RL, APP, que diz respeito, onde estão, a quem pertence; se são áreas consolidadas ou se necessitam realizar algum passivo ambiental. Ainda é possível verificar se as respectivas áreas pertencem a comunidades indígenas ou quilombolas de todo o Brasil. Diante desta informação faremos um adendo no que se refere às terras dos assentados da reforma agrária e quilombolas, no qual é "responsabilidade do Governo Federal, a atribuição de cadastrar as terras, e do Incra, que fará o mapeamento sobre toda a área do assentamento. Se o assentamento for de responsabilidade estadual ou municipal, o CAR será feito por seus órgãos ambientais responsáveis", (Confederação Nacional dos Trabalhadores na Agricultura-CNTA, 2014).

Entende-se que os dados registrados em todo território Nacional, convergem para o SICAR, inclusive os dados coletados pelos Estados que possuem sistema próprio de cadastramento, na Tabela 1 podemos verificar o sistema adotado por cada Unidade Federativa, no qual se observa que os Estados do Bahia, Espírito Santo, Mato Grosso do Sul, São Paulo e Tocantins, possuem sistema próprio de cadastramento, que posteriormente serão repassadas para o SICAR. Seis Estados utilizam o Sub-módulo do SICAR no qual a central de dados é estadual, o cadastro realizado por estes apresentam algumas informações específicas dos Estados que o utilizam. E os demais Estados são utilizados o Módulo do SICAR. 
Tabela 1. A utilização de dados e informações pelos Estados brasileiros no SICAR.

\begin{tabular}{|c|c|c|c|}
\hline ESTADOS & $\begin{array}{l}\text { UTILIZA SISTEMA DE } \\
\text { CADASTRO PRÓPRIO }\end{array}$ & $\begin{array}{l}\text { SUB-MÓDULO } \\
\text { DO SICAR }\end{array}$ & $\begin{array}{l}\text { MÓDULO DO } \\
\text { SICAR }\end{array}$ \\
\hline Acre (AC) & & $\mathrm{X}$ & \\
\hline Alagoas (AL) & & & $\mathrm{X}$ \\
\hline Amapá (AP) & & & $\mathrm{X}$ \\
\hline Amazonas (AM) & & & $\mathrm{X}$ \\
\hline Bahia (BA) & $\mathrm{X}$ & & \\
\hline Ceará (CE) & & & $\mathrm{X}$ \\
\hline Distrito Federal (DF) & & & $\mathrm{X}$ \\
\hline Espírito Santo (ES) & $\mathrm{X}$ & & \\
\hline Goiás (GO) & & & $\mathrm{X}$ \\
\hline Maranhão (MA) & & & $\mathrm{X}$ \\
\hline Mato Grosso (MT) & & $\mathrm{X}$ & \\
\hline Mato Grosso do Sul (MS) & $\mathrm{X}$ & & \\
\hline Minas Gerais (MG) & & $\mathrm{X}$ & \\
\hline Pará (PA) & & $\mathrm{X}$ & \\
\hline Paraíba (PB) & & & $\mathrm{X}$ \\
\hline Paraná (PR) & & & $\mathrm{X}$ \\
\hline Pernambuco (PE) & & & $\mathrm{X}$ \\
\hline Piauí (PI) & & & $\mathrm{X}$ \\
\hline Rio de Janeiro (RJ) & & & $\mathrm{X}$ \\
\hline Rio Grande do Norte (RN) & & & $\mathrm{X}$ \\
\hline Rio Grande do Sul (RS) & & $\mathrm{X}$ & \\
\hline Rondônia (RO) & & $\mathrm{X}$ & \\
\hline Roraima (RR) & & & $\mathrm{X}$ \\
\hline Santa Catarina (SC) & & & $\mathrm{X}$ \\
\hline São Paulo (SP) & $\mathrm{X}$ & & \\
\hline Sergipe (SE) & & & $\mathrm{X}$ \\
\hline Tocantins & $\mathrm{X}$ & & \\
\hline
\end{tabular}

Fonte: Adaptado do (MMA/SFB, 2017b).

Lembrando que, os Estados podem desenvolver o seu próprio sistema, uma vez que respeite seus limites territoriais e nos casos de propriedades que estão localizadas em áreas de divisa, (entre Estados), o proprietário decide onde realizará o CAR. Alguns órgãos Estaduais responsáveis pelo cadastramento a exemplo da Superintendência de Administração do Meio Ambiente da Paraíba (SUDEMA) recomenda que esse seja efetuado no Estado onde se encontra a área com maior extensão territorial a ser cadastrada, realizando assim cadastro único de toda a área (destaque das autoras).

Verificaram-se ao longo desta pesquisa, que o sistema do CAR possui diversos materiais de apoio como módulos, cartilhas, folhetos e outros que auxiliam o cadastrante, no preenchimento dos dados solicitados no SICAR, conforme o MMA (2016b):

[...] Além de explicar claramente os passos que devem ser seguidos para completar cada fluxo, a fim de esclarecer qualquer dúvida sobre a utilização do sistema. Visando dar assistência aos usuários do sistema, os autores deste guia utilizam uma linguagem clara e simples de modo a chegarem à maior quantidade possível de receptores.

Para o preenchimento do cadastro é necessário ter conhecimento básicos de informática, em situações nos quais os proprietários ou possuidores não obtenham êxito ao efetuar 
esse, os mesmos podem buscar orientações junto aos órgãos ambientais Municipais ou Estaduais, contratar profissionais ou empresa para realizá-lo.

\section{PROGRAMA DE REGULARIZAÇÃO AMBIENTAL}

O referido sistema possui cinco etapas em seu preenchimento (Tabela 2), antes é preciso entrar no site www.car.gov.br, no qual, este abrirá na tela inicial do SICAR, em seguida deve-se baixar o Módulo de cadastro; selecionar o Estado onde será realizado o cadastro, escolha o office, após o download prossiga com o preenchimento das etapas.

Tabela 2. Procedimentos para o preenchimento do SICAR

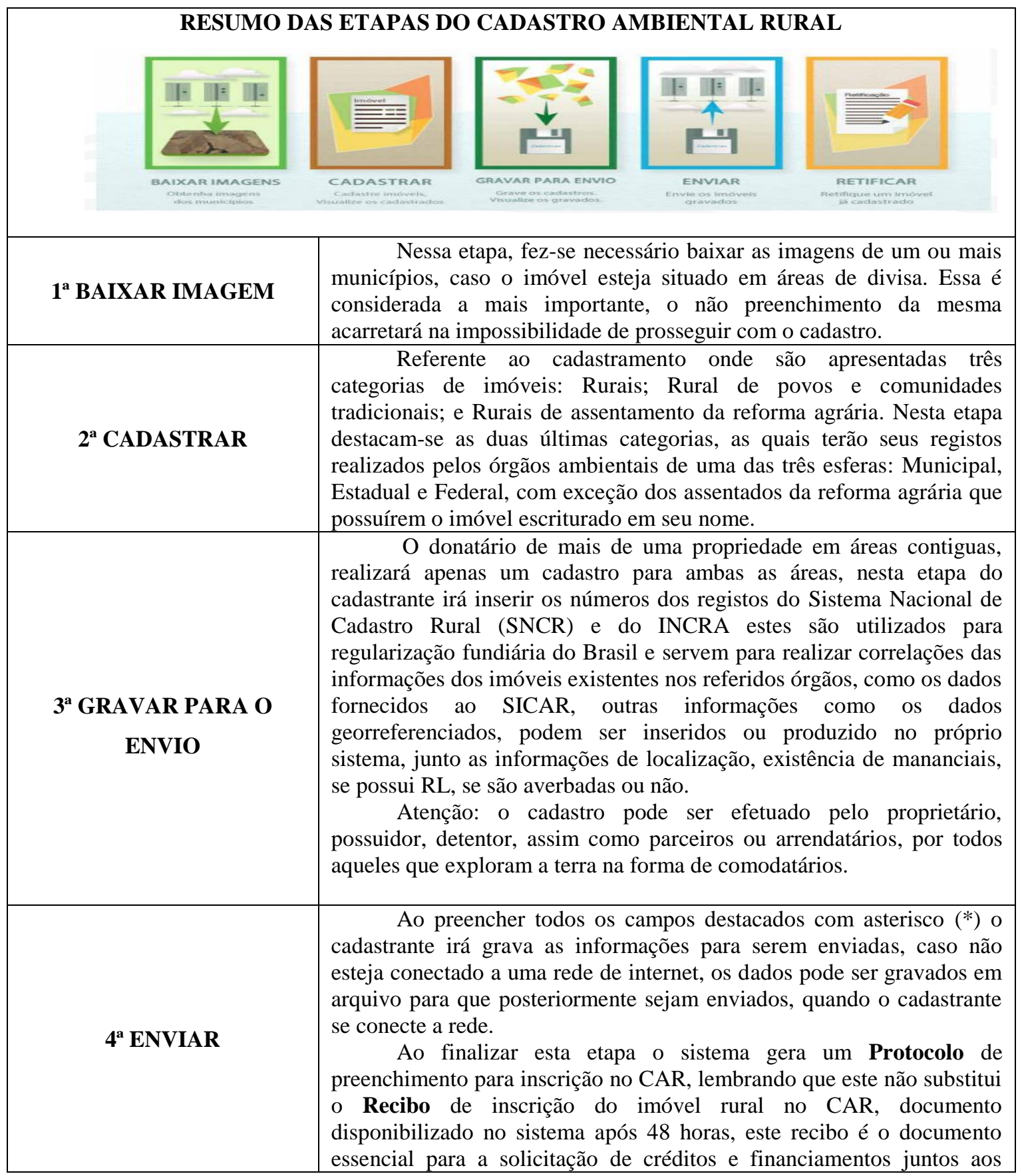




\begin{tabular}{|c|l|}
\hline & $\begin{array}{r}\text { bancos. } \\
\text { Ainda nesta etapa a análise dos dados fornecidos, passa a ser de } \\
\text { "responsabilidade dos órgãos ambientais" em suas respectivas esferas. } \\
\text { Ressalta-se que o órgão ambiental poderá realizar vistorias nas } \\
\text { propriedades cadastradas e caso necessário solicitar ao declarante outros } \\
\text { documentos, que esclareçam as dúvidas sobre os dados fornecidos no } \\
\text { sistema em comparação com a vistoria realizada in loco. }\end{array}$ \\
\hline $5^{\text {a RETIFICAR }}$ & $\begin{array}{l}\text { Essa etapa só será utilizada ao final de todo o cadastro, caso o } \\
\text { cadastrante tenha percebido algum erro no ato do preenchimento, no } \\
\text { qual o mesmo só ira retificar o erro, não sendo necessário refazer todo o } \\
\text { processo de cadastro. }\end{array}$ \\
\hline
\end{tabular}

Fonte: Base de dados, MMA-SICAR (2016c).

Conforme o Decreto $\mathrm{n}^{\mathrm{o}}$ 7.830/2012 é necessário que ocorra a integração das informações com a base de dados do SICAR, em seu Art. $6^{\circ}$, nos incisos do primeiro ao quarto, trata da obrigatoriedade da inscrição:

$1^{\circ}$ As informações são de responsabilidade do declarante, que incorrerá em sanções penais e administrativas, sem prejuízo de outras previstas na legislação, quando total ou parcialmente falsas, enganosas ou omissas.

$2^{\circ} \mathrm{A}$ inscrição no CAR deverá ser requerida no prazo de 1 (um) ano contado da sua implantação, preferencialmente junto ao órgão ambiental municipal ou estadual competente do Sistema Nacional do Meio Ambiente - SISNAMA.

$3^{\circ}$ As informações serão atualizadas periodicamente ou sempre que houver alteração de natureza dominial ou possessória.

$4^{\circ} \mathrm{A}$ atualização ou alteração dos dados inseridos no CAR só poderão ser efetuadas pelo proprietário ou possuidor rural ou representante legalmente constituído.

Obedecendo ao conteúdo desse Decreto, após o registo no sistema, o proprietário que apresentar algum tipo de irregularidade em seu cadastro, poderá aderir ao Programa de Regularização Ambiental (PRA), para adequar o imóvel a legislação ambiental vigente. O PRA, foi criado a partir do Decreto 8.235/2014, que:

Restringem-se à regularização das Áreas de Preservação Permanente APP, de Reserva Legal - RL e de uso restrito das áreas desmatadas até 22/07/2008 ocupadas por atividades agrossilvipastoris, que poderá ser efetivada mediante recuperação, recomposição, regeneração ou compensação. A compensação aplica-se exclusivamente às Áreas de Reserva Legal - RL suprimidas até 22/07/2008. Realizada a inscrição no CAR, os proprietários ou os possuidores de imóveis rurais com passivo ambiental relativo às APP, RL e áreas de uso restrito poderão solicitar de imediato a adesão aos Programas de Regularização Ambiental-PRA dos Estados e do Distrito Federal para proceder à regularização ambiental do seu imóvel rural, (MMA, 2017c). 
Conforme o Art. $4^{\circ}$, inciso primeiro, a adesão ao PRA estabelece que seja assinado um termo de compromisso por imóvel rural, trazendo no escopo do mencionado Decreto, uma série de informações referente à APP e RL, assim existentes na área cadastrada. $\mathrm{O}$ PRA é o tema de grande repercussão na revisão do Código Florestal de 2012.

\section{DISCUSSÕES SOBRE A REFORMULAÇÃO DA LEI 12.651 DE 5 DE MAIO DE $2012(2017-2018)$}

Perante as informações expostas nesta pesquisa, nota-se que o Brasil vem buscando algumas soluções que "proporcione melhores condições ambienteis" para o País, evidentemente que estas não podem ser consolidadas sem a intervenção política e principalmente econômica.

Essas questões tornam-se mais evidente a partir da criação Lei 12.651/12. Mencionada anteriormente, esta Lei é alvo de diversas polemicas e recentemente está passando por um processo de revisão de seus artigos, a ação entra na pauta do Supremo Tribunal Federal (STF) em 2017, sendo cinco ações que discutem 21 de seus artigos. No mesmo ano, houve a solicitação para a realização de vistas do CodFlo, com isso dar-se início ao julgamento das contestações, mas segundo o STF:

Pedido de vista da presidente do Supremo Tribunal Federal (STF) ministra Cármen Lúcia, suspendeu o julgamento de ações que questionam o novo Código Florestal (Lei 12.651/2012). Na sessão [...], o relator da matéria, ministro Luiz Fux, apresentou ao Plenário seu voto, no qual analisou diversos dispositivos questionados e afastou a constitucionalidade de alguns deles. Estão sendo julgadas em conjunto a Ação Declaratória Constitucionalidade (ADC) 42 e as Ações Diretas de Inconstitucionalidade (ADIs) 4901, 4902, 4903 e 4937 (STF, 2017a).

No que corresponde as ADIs 4901, 4902 e 4903, foram avaliadas pela ProcuradoriaGeral da República, a ADI 4937, foi formulada pelo Partido Socialismo e Liberdade (PSOL), que alegam inconstitucionalidade de alguns dispositivos do Novo Código Florestal. No que corresponde a ADC 42, de autoria do Partido Progressista (PP) defende a constitucionalidade da Lei (STF, 2017b). Perante as discussões em relação Código, no Quadro3, observamos alguns dos Artigos que foram debatidos pelos ministros durante as sessões, está discussão se desdobrou sobre a luz das Ações Declaratórias. 
Tabela 3. Artigos Discutidos Pelos Ministros do STF

\begin{tabular}{|c|c|c|}
\hline ARTIGO & COMENTÁRIOS & CONSIDERADO \\
\hline Art.3 & $\begin{array}{l}\text { - Extensão do tratamento dispensado à pequena propriedade ou } \\
\text { propriedade familiar aos imóveis até } 4 \text { módulos fiscais; } \\
\text { - Alteração do conceito de leito regular. }\end{array}$ & Constitucional \\
\hline Art. 4 & $\begin{array}{l}\text { - Exclusão das APPs no entorno de reservatórios artificiais de água } \\
\text { que não decorram de barramento ou represamento de cursos d'água } \\
\text { naturais e nas acumulações naturais ou artificiais de água com } \\
\text { superfície inferior a } 1 \text { (um) hectare; uso agrícola de várzeas em } \\
\text { pequena propriedade ou posse rural familiar; } \\
\text {-Uso agrícola de várzeas em pequena propriedade ou posse rural } \\
\text { familiar. }\end{array}$ & Constitucional \\
\hline Art. 5 & $\begin{array}{l}\text { - Redução da largura mínima da APP no entorno de reservatório } \\
\text { d'água artificial destinado à geração de energia ou abastecimento } \\
\text { público }\end{array}$ & Constitucional \\
\hline Art. 8 & $\begin{array}{l}\text { - Impossibilidade de intervenção em restingas e manguezais para } \\
\text { execução de obras habitacionais e de urbanização, inseridas em } \\
\text { projetos de regularização fundiária de interesse social, em áreas } \\
\text { urbanas consolidadas ocupadas por população de baixa-renda. }\end{array}$ & Constitucional \\
\hline Art. 11 & $\begin{array}{l}\text { - Uso restrito do manejo florestal sustentável e o exercício de } \\
\text { atividades agrossilvipastoris em áreas de inclinação entre } 25^{\circ} \mathrm{e} \\
45^{\circ} \text {; }\end{array}$ & Constitucional \\
\hline Art. 12 & $\begin{array}{l}\text { - Hipóteses de redução da Reserva Legal; } \\
\text { - Possibilidade de redução da Reserva Legal em face da existência, } \\
\text { no Município, de } 50 \% \text { (cinquenta por cento) da área ocupada por } \\
\text { unidades de conservação da natureza de domínio público e por } \\
\text { terras indígenas homologadas. }\end{array}$ & Constitucional \\
\hline Art. 13 & $\begin{array}{l}\text { - Redução em } 50 \% \text { da reserva legal para fins de regularização, } \\
\text { mediante recomposição, regeneração ou compensação da Reserva } \\
\text { Legal de imóveis com área rural consolidada, situados em área de } \\
\text { floresta localizada na Amazônia Legal. }\end{array}$ & Constitucional \\
\hline Art. 15 & $\begin{array}{l}\text { - Computo de área de preservação permanente e reserva legal; } \\
\text { - imóveis rurais com até } 15 \text { (quinze) módulos fiscais, que esteja } \\
\text { inscrito no Cadastro Ambiental Rural - CAR. }\end{array}$ & Constitucional \\
\hline Art. 26 & $\begin{array}{l}\text { - A supressão de vegetação nativa para uso alternativo do solo, } \\
\text { tanto de domínio público como de domínio privado, dependerá do } \\
\text { cadastramento do imóvel no CAR, de que trata o art. } 29 \text {. }\end{array}$ & Constitucional \\
\hline Art. 61 & - Regularização de áreas rurais consolidadas & Constitucional \\
\hline Art. 66 & - Cumprimento da reserva legal por compensação ou doação. & Constitucional \\
\hline Art. 67 & - Regime diferenciado para reserva legal em áreas já ocupadas. & Constitucional \\
\hline Art. 68 & $\begin{array}{l}\text { - Imóveis rurais que detinham, em } 22 \text { de julho de } 2008 \text {, área de até } \\
4 \text { (quatro) módulos fiscais e que possuam remanescente de } \\
\text { vegetação nativa. }\end{array}$ & Constitucional \\
\hline Art. 7 & $\begin{array}{l}\text { - Recomposição de vegetação; } \\
\text { - caso de supressão não autorizada de vegetação realizada após } 22 \\
\text { de julho de } 2008 \text { é vedado à concessão de novas autorizações de } \\
\text { supressão de vegetação enquanto não cumpridas as obrigações } \\
\text { previstas no } § 1^{\circ} \text {. }\end{array}$ & Inconstitucional \\
\hline Art. 17 & $\begin{array}{l}\text { - Admite-se a exploração econômica da Reserva Legal mediante } \\
\text { manejo sustentável, previamente aprovado pelo órgão competente } \\
\text { do SISNAMA, de acordo com as modalidades previstas no art. } 20 \text {. }\end{array}$ & Inconstitucional \\
\hline Art. 59 & $\begin{array}{l}\text { - As petições solicitaram a inconstitucionalidade dos parágrafos } 4 .^{\circ} \\
\text { e } 5 .^{\circ} \text { (dispensa de multas), do referente artigo. }\end{array}$ & Inconstitucional \\
\hline
\end{tabular}




\begin{tabular}{|l|l|l|}
\hline Art. 60 & $\begin{array}{l}\text { - Suspende processos criminais e extingue a punibilidade, caso } \\
\text { sejam cumpridas as obrigações assumidas no Termo de } \\
\text { Compromisso firmado no PRA. }\end{array}$ & \\
\hline
\end{tabular}

Fonte: Adaptado de V. Guimarães, 2017 e E. Miranda, 2018.

Entende-se que houve e haverá inúmeros debates a respeito dos artigos da Lei 12.651, em razão desta que ao passar por qualquer alteração em seus dispositivos afetará diretamente ou indiretamente os interesses dos empresários do agronegócio brasileiro.

De forma geral destacam-se dois dispositivos considerados como os mais polêmicos, apresentado pelo Ministro relator Luiz Fux. O primeiro que trata da isenção de recomposição de áreas desmatadas para pequenas propriedades rurais. O segundo trata da anistia, que é o perdão das multas e extinção de processos por crimes ambientais, desde que haja recuperação das áreas degradadas, foram considerados constitucionais e mantidos pela Suprema Corte.

O Ministro Relator entendeu pela inconstitucionalidade da expressão 'realizadas após 22 de julho de 2008', com o fundamento de que "ao isentar os causadores da obrigação de reparar os danos, sem que seja exigida qualquer circunstância que signifique impedimento para o cumprimento deste dever, verifica-se patente a violação ao artigo 225 , $\S 1^{\circ}, 3^{\circ}$ e $4^{\circ}$, e do artigo 186 da Constituição Federal" e que não há justificativa racional para o marco temporal apresentado pelo legislador (Guimarães, 2017).

Estes dispositivos no entendimento de alguns membros do STF fere a Constituição ao não exigir dos proprietários de terras a realização da recomposição ou a compensação das áreas desmatadas antes de 22 de maio de 2008, deixando um registo de mais de 371 mil $\mathrm{Km}^{2}$ de áreas desmatadas, conforme dados do MMA em 2017. O resultado do julgamento no STF foi favorável por seis votos a cinco, mantendo a anistia.

A anistia foi um dos pontos discutido e o que gerou diversas dúvidas na decisão dos votos dos Ministros, sendo os Artigos 59 e 60 que instituem o Programa de Regularização Ambiental, foram analisados e entendidos como inconstitucionais pela minoria dos Ministros, estes artigos confere ao infrator a anistia condicional, violando o início $3^{\circ}$ do artigo 225 da Constituição Federal, que "impede a interpretação de que a reparação do dano seja fungível em relação ao cumprimento de sanções penais e administrativas aplicáveis aos causadores de danos. Trata-se de obrigações cumulativas e não alternativas ou sucessivas por expressa determinação constitucional" (Guimarães, 2017).

Mediante os diversos artigos que foram sabatinados pelo STF, iremos nos ater aos mais polemizados, sendo assim, ao observamos o processo da revisão do Código Florestal de 2012, onze Ministros proferiram seus votos, participaram da votação os Ministros: Luiz Fux, Edson Fachin, Luiz Roberto Barroso, Marco Aurélio e Ricardo Lewandowisk, estes entenderam que a anistia deveria ser derrubada, por acreditar que estes artigos (59 e 60) ferem a Constituição Federal. Conforme podemos verificar nos votos dos Ministros Luiz Fux e Luiz Roberto Barroso.

O Programa de Regularização Ambiental (PRA) foi considerado pelo Ministro Luiz Roberto Barroso, uma forma de anistia aos produtores rurais e declarado inconstitucional. Segundo Luiz Fux, o programa 
tem por objetivo a adequação das Áreas de Proteção Permanente (APPs) e de Reserva Legal de propriedades rurais por meio de recuperação ou compensação, firmando termo de compromisso. A adesão ao programa confere benefícios, suspendendo sanções por infrações anteriores a 22 de julho de 2008 e afastando penalidades administrativas e punibilidade por crimes ambientais. [...] Trata-se de obrigações cumulativas e não alternativas, e o legislador não poderia, mesmo com o objetivo de promover a recuperação de áreas desmatadas, criar programa de recuperação que torne as obrigações intercambiáveis. Além disso, a medida configura um estímulo ao desmatamento, o qual tem aumentado desde a aprovação do Código Florestal-2012 (STF, 2017a).

Ao conceder isenção de possíveis multas, sanções administrativas e crimes ambientais anteriores a 2008, o Código Florestal de 2012 demostrou uma despreocupação por parte do Estado para com o direito ambiental, desta forma o Ministro Luiz Fux considerou os artigos acima mencionados inconstitucionais por violar a Constituição Federal.

No voto do Ministro Luiz Roberto Barroso:

Sobre o tema da anistia a sanções para agricultores que aderirem ao Programa de Regularização Ambiental, o ministro considerou não haver inconstitucionalidade em si na suspensão ou extinção da responsabilidade administrativa ou criminal dos atos lesivos ao meio ambiente, havendo, porém, um problema de proporcionalidade na norma. "Impõe severo ônus ao meio ambiente, mas gera benefícios ínfimos em razão da estabilização de situações jurídicas consolidadas" (STF, 2018a).

O Ministro ainda considerou e seguiu a linha de pensamento Ministro Luiz Fux, votando inconstitucional a anistia assegurada no Código em questão, e também acrescentou "alguns dispositivos relativos à possiblidade de redução em até $50 \%$ na Reserva Legal de propriedades, em alguns casos" (Nelson, 2018). E expõe uma defesa pujante sobre a Amazônia:

O Brasil ainda trata a Amazônia como se fosse passivo e não como um dos maiores ativos do mundo. O mundo precisa da Amazônia e o Brasil precisa da Amazônia. Precisamos pensar em prol de desmatamento zero, que significa recompor tudo aquilo que foi desmatado. O Brasil e o mundo deveriam pensar em recompensar a Amazônia (Nelson, 2018).

Quanto ao Ministro Edson Fachin ao expressar seu voto sobre a Ação de constitucionalidades e ou inconstitucionalidades, esse concorda com o Ministro Luiz Roberto Barroso no que trata o Artigo 13, sobre a redução em até 50\% na Reserva Legal, durante a sua explanação ele também se ateve a discursão dos artigos 59 e 60 do CodFlor, segundo reportagem do Instituto Socioambiental (ISA) que acompanha de perto a votação do CodFlo de 2012, destaca a fala do referido Ministro:

O ministro defendeu com veemência a importância das APPs e condenou a anistia a desmatamentos ilegais. "Não se pode prestigiar infratores em detrimento daqueles que sempre arcaram com o ônus econômico de observar o ordenamento jurídico". A prosperar esse 
raciocínio, os produtores rurais sempre terão incentivos para desmatar, aguardando nova legislação, nova anistia (ISA, 2018a).

Os demais ministros que votaram pelo fim da anistia, seguiram o mesmo posicionamento do Ministro Relator, mantendo-se assim as Ações na forma as quais foram por ele apresentado. Ainda na mesma sessão da Suprema Corte, manifestaram-se os Ministros Gilmar Mendes, Alexandre Moraes, Rosa Weber, Dias Toffoli, Presidente da Corte a Ministra Carmem Lúcia, além do Ministro Celso Mello responsável por realizar o desempate da votação, realizado em outra sessão. Nesta ocasião, segundo o STF o Ministro Gilmar Mendes foi:

Único a votar até o momento pela total improcedência de todas as ADIs e pela procedência da ADC, o Ministro Gilmar Mendes afastou a aplicação ao caso do princípio da proibição do retrocesso. Ele ressaltou que o Código Florestal é uma lei "extremamente técnica", resultado de mais de 200 audiências públicas que contaram com a participação de todos os setores representativos da sociedade relacionados à matéria (STF, 2018b).

Diante desta alegação o Ministro Mendes expôs em seu discurso:

Defendeu uma nova visão holística do direito ambiental, "sem as amarras radicalmente ecológicas", sem que se atinja o núcleo essencial da proteção nem os tratados internacionais firmados pelo Brasil, nem se esvazie o desenvolvimento sustentável previsto na Constituição Federal, que visa compatibilizar o interesse econômico e empresarial com a proteção ao meio ambiente (STF, 2018b).

Ao observar as palavras do referido Ministro, o mesmo posiciona-se pela inalteração dos artigos discutidos no Código Florestal Brasileiro. Sendo assim após sua fala, se pronunciou a Presidente do STF, Ministra Cármen Lúcia, no qual realizou alguns apontamentos a respeito das revogações de alguns dispositivos do CodFlo de 2102, principalmente no que se trata de uma maior proteção do meio ambiente, em questões de intervenção ou supressão da vegetação em APP's.

A Ministra também realizou exposição dos votos dos Ministros presentes na sessão, e na sequência ressalvou de maneira sucinta a sua posição perante a explanação do Ministro Luiz Fux. Segundo o Supremo "O critério usado pela ministra foi impedir que o retrocesso socioambiental, vetando medidas que reduzam o nível de proteção ao meio ambiente sem propor medidas compensatórias". No que diz respeito ao debate do Programa de Regularização Ambiental a Ministra afirma que:

A lei não institui anistia aos agricultores, uma vez que eles continuam sujeitos a punições em caso de descumprimento dos programas de regularização. A fórmula adotada pela lei estimularia o infrator a recuperar a área degradada, [...]. "Mesmo para fatos ocorridos antes de 22 de julho de 2008 os infratores ficam sujeitos à autuação e punição se descumprirem os ajustes firmados nos termos de compromisso medidas administrativas a serem aplicadas se não forem recompostas as partes degradadas de Área de Proteção Permanente ou Reserva Legal, para que o infrator seja transformado em agente de recuperação das áreas degradadas" (STF, 2018c). 
Diante do voto da Presidente do Supremo entende-se que a sua interpretação, esta em conformidade com o artigo 59 do Código em questão, afastando assim a possibilidade de se impor medida punitivas compensatórias, aos donatários e possuidores de terras que realizaram atos ilícitos, antecedente a 22 de junho de 2008, bem como infrações dela decorrentes. Os demais Ministros Alexandre Moraes, Rosa Weber, Dias Toffoli, e Ministro Celso Mello que proferiu o voto decisivo pela a permanência da anistia, estes apresentaram seus votos realizando em defesa ao que acreditam ser pertinentes a serem alterados no CodFlo. No qual observamos o retrocesso na Lei em prol do meio ambiente, como site do Instituto Socioambiental (ISA).

O retrocesso é considero muito relevante as pontuais correções feitas pelo STF, que vão permitir: estender a proteção às nascentes intermitentes; restringir desmatamentos em Áreas de Preservação Permanente (APPs) apenas para situações em que não exista alternativa; ampliar o tratamento diferenciado da lei às Terras Indígenas ainda não demarcadas e aos quilombos ainda não titulados; vedar intervenções degradantes em APPs para a implantação de aterros sanitários e equipamentos esportivos; condicionar a "compensação" de Reserva Legal no mesmo bioma, quando realizada por Cota de Reserva Ambiental, à equivalência ecológica entre as áreas envolvidas (ISA, 2018b).

Contudo, entendemos que o Código Florestal foi e ainda é amplamente repercutido de acordo com algumas matérias jornalísticas nacionais, divulgadas em Jornais de grande circulação como o Estadão, Jornal Globo e Jornal do Brasil, com respectivas as chamadas: Confirmação do Código Florestal; STF mantém anistia a desmatadores no "novo" Código Florestal; Novo Código Florestal cinco anos depois: Implementação pelos Estados é lenta e legislação é questionada pelo STF.

Além das matérias internacionais, a exemplo do Jornal BBC com a capa da matéria "STF decide se anistia do novo Código Florestal a quem desmatou é válida", além de sites como Instituto Socioambiental (ISA) e World Wildlife Fund (WWF), que traz em seus conteúdos discussões ambientais relevantes, estas matérias afirmam que o Brasil por meio das ações que estão sendo discutidas, concede o perdão de multas estimadas em aproximadamente de $\mathrm{R}$ \$ 8,4 bilhões, além de favorecer a permanência da anistia. Reforçando esta discussão o Instituto Socioambiental afirma que:

Assim, o STF legitimou a anistia aos desmatamentos ilegais ocorridos até 2008, permitindo que a maior parte das áreas indevidamente desflorestadas no passado continue sendo utilizada nas atividades agropecuárias, dispensando-se a recomposição. Com isso, referendou um duplo regime jurídico em que propriedades detentoras de passivos florestais ficarão sujeitas a obrigações mais brandas de proteção da vegetação e com maior área para produzir, enquanto aqueles imóveis rurais legalmente regulares ficarão desvalorizados por permanecer obrigados a maiores exigências legais (ISA, 2018b).

Agora o STF publicará os acórdãos ${ }^{8}$ dos pontos levantados na discussão do CodFlo, para que sejam debatidos por representantes do setor agropecuário, que a depender do

\footnotetext{
${ }^{8}$ Segundo Oliveira (2008) acórdão é a conclusão, a decisão ou parte final; enfim, o desfecho da demanda, onde, aplicando a lei ao caso concreto, o julgador acolhe ou rejeita o pedido formulado pela parte.
} 
entendimento podem dar entrada em Embargos Declaratórios ${ }^{9}$, na tentativa de obter maiores esclarecimentos sobre os dispositivos que foram julgados.

\section{CONSIDERAÇÕES FINAIS}

Diante do exposto podemos considerar que até chegar à instauração do Cadastro Ambiental Rural, um longo caminho foi trilhado, perpassando por diversos Decretos, Códigos e Leis, observa-se que registros anteriores ao CAR ainda se encontram em vigor, como o Registo de Imóveis, por exemplo, e que se desenvolveu concomitantemente com o CAR. Com o advento da Lei 12.651/2012, este Cadastro é considerado como um dos principais instrumentos da Legislação ambiental brasileira, favorecendo o controle e o monitoramento dos remanescentes florestais existentes no Território Nacional, além de contribuir com a ampliação gerenciamento ambiental nas propriedades rurais.

Perante os dados registrados no SICAR, poderemos afirmar que o Código Florestal de 2012, trouxe em sua conjuntura, regras que auxiliam na preservação e conservação das áreas destinadas as APP's, bem como a implantação da RL, favorecendo uma visão geral da distribuição espacial do CAR, em todo Brasil. Assim, o CAR enquanto instrumento de gestão pública tem otimizado as tomadas de decisões para um melhor planejamento e ordenamento territorial rural, tornando-se importante por realizar a delimitação geográfica dos imóveis e consequentemente uma melhor gestão dos recursos naturais em âmbito nacional.

Atualmente os artigos do Código Florestal de 2012, passou por ampla discussão no Supremo Tribunal Federal, dos quais os artigos 59 e 60 que tange sobre o PRA e anistia concedida aos proprietários de terras, resguardados pelo referido Código, estes dois artigos dos 21 em discussão, toram-se uns dos principais pontos arrolados no processo, travando discussões entre os Ministros do Supremo Tribunal Federal, agropecuaristas, ambientalistas e sociedade de forma geral, mediante as Ações Declaratórias constitucionais e inconstitucionais apresentadas ao STF. No enceramento do julgamento no dia 28 de fevereiro de 2018, foi mantida a anistia aos donos de terras que realizaram atos ilícitos sobre o maio ambiente anterior a 2008.

Entende-se que ao manter inalterado o Inciso $4^{\circ}$ do Art. 59 do Código Florestal, que trata da anistia, este artigo exime o proprietário da obrigatoriedade de recompor as áreas alteradas, degradadas ou instintas, acarretando prejuízos de cunho ambiental, por compreender que as áreas outrora degradadas não necessitariam ser recuperada, isso causa inúmeros impactos ambientais, como a perda de biodiversidade, redução das matas ciliares, aumento de assoreamentos dos rios, além da redução da Reserva Legal de $80 \%$ para $50 \%$ - em municípios na Amazônia no qual 50\% de seu território estejam ocupados por Terras Indígenas ou Unidades de Conservação.

Assim como nos demais Estados da Federação com mais de $65 \%$ do território ocupado por Terras Indígenas ou Unidades de Conservação; pode conceder permissão para

\footnotetext{
${ }^{9}$ Segundo Alves (2004) possuem natureza jurídica de recurso, bem como foram demonstrados que os Embargos possuem o efeito interruptivo, devolutivo e suspensivo. Todavia, em algumas hipóteses podem ocorrer contradição e omissão que ensejem a modificação da decisão, é o que chamamos de efeitos infringentes.
} 
realizar atividades agropecuárias em APPs e nos topos dos morros; Pequenas propriedades podem seguir critérios menos rígidos para recuperar APPs nas margens dos rios.

Ao tratar-se dos ganhos após a discussão do Código, foram os seguintes: a proibição de desmatamento em APP's, para finalidades de implantar depósitos de lixo ou instalações esportivas; a ampliação da proteção das nascentes e olhos d'água que sejam intermitentes.

Diante do que foi elencado no artigo, lembramos que as Ações Declaratórias tanto constitucionais como inconstitucionais, foram pleiteadas para um melhor aperfeiçoamento da Lei 12.651/12, em prol de um meio ambiente mais equilibrado, entende-se que as decisões do Supremo Tribunal Federal "ainda podem sofrer embargos declaratórios", gerando cenários de amplos debates entorno do Código Florestal Brasileiro.

Conclui-se que discussões das legislações ambientais brasileiras são necessárias, pelo fato de estarmos inseridos em um sistema dinâmico, que necessita do olhar atento da sociedade para que a legislação ambiental, seja cumprida de forma hormônica, contribuindo para a sua proteção, manutenção e desenvolvimento ambiental e assim, o meio ambiente possa-nos fornecer o fomento necessário para o desenvolvimento e o bem-estar humano, assim o CAR, como um instrumento incluído no "Novo" Código Florestal Brasileiro, em seus cinco anos, discretamente esta sendo motivos de estudos, por ser uma ferramenta de suma importância para regulação da proteção ambiental no País.

\section{REFERÊNCIAS}

AZEVEDO, A. A. Do licenciamento ao cadastro ambiental rural (CAR): Experiência de Mato Grosso. Rio de Janeiro: Graramund, 2014.

BNDES. Banco Nacional de Desenvolvimento Econômico e Social, 2017. Cadastro Ambiental Rural: conceito, abrangência, escopo e natureza. Brasília. Disponível: $<$ https://www.bndes.gov.br/wps/portal/site/home/conhecimento/noticias/noticia/cadastr o-ambiental-rural>. [Acesso: 25 de set de 2017].

BRASIL. Lei $N^{o} 4.504$ de 30 de novembro1964. Dispõe sobre o Estatuto da Terra, e dá outras providências, Brasília- DF. Disponível em 〈http://www.planalto.gov.br/ccivil_03/leis/L4504.htm>. [Acessado em 10 de Jan. 2018].

BRASIL. Lei $N^{o} 4.771$ de 15de Setembro1965, Institui o novo Código Florestal. Brasília: Brasília - DF. Disponível: $<$ http://www.planalto.gov.br/ccivil_03/LEIS/L4771.htm>. [Acessado em: 10 de Jan. $2018]$.

BRASIL. Lei $N^{o} 5.868$ de 12 de Dezembro1972, Cria o Sistema Nacional de Cadastro Rural, e dá outras providências. Brasília-DF. Disponível : 
<http://www.planalto.gov.br/ccivil_03/LEIS/L5868.htm>. [Acessado em: 13 de Jan. 2018].

BRASIL. Lei $N^{o} 6.015$ de 31 de Dezembro 1973, Dispõe sobre os registros públicos, e dá outras providências. Brasília-DF. Disponível: <http://www.planalto.gov.br/ccivil_03/leis/L6015compilada.htm>. [Acessado em: 14 de Jan. 2018]

BRASIL. Lei $N^{o} 6.938$ de 31 de Agosto1981, Dispõe sobre a Política Nacional do Meio Ambiente, seus fins e mecanismos de formulação e aplicação, e dá outras providências. Brasília-DF. Disponível: 〈http://www.planalto.gov.br/ccivil_03/leis/L6938.htm>. [Acessado em: 28 de Jan. 2018].

BRASIL. Lei $N^{o} 10.406$ de 10 de Janeiro 2002, Institui o Código Civil. Brasília-DF. Disponível: <http://www.planalto.gov.br/ccivil_03/LEIS/2002/L10406.htm>. [Acessado em: 6 de Fev. 2018].

BRASIL. Decreto $N^{o} 7.029$ de 10 de Dezembro2009, Institui o Programa Federal de Apoio à Regularização Ambiental de Imóveis Rurais, denominado "Programa Mais Ambiente", e dá outras providências. Brasília-DF. Disponível: <http://www.planalto.gov.br/ccivil_03/_Ato2007-2010/2009/Decreto/D7029.htm>.

[Acessado em: 5 de Jan. 2018].

BRASIL. Lei $n^{o} 12.651$, de 25 de maio de 2012 a. Dispõe sobre a proteção da vegetação nativa; altera as Leis nos 6.938, de 31 de agosto de 1981, 9.393, de 19 de dezembro de 1996, e 11.428, de 22 de dezembro de 2006; revoga as Leis nos 4.771, de 15 de setembro de 1965, e 7.754, de 14 de abril de 1989, e a Medida Provisória no 2.166-67, de 24 de agosto de 2001; e dá outras providências. Brasília-DF. Disponível: <http://www.planalto.gov.br/ccivil_03/_ato2011-2014/2012/lei/112651.htm>. [Acessado em: 17 de Jan. 2018].

BRASIL. Decreto $N^{o} 7.830$ de 17 de Outubro de 2012 b, Dispõe sobre o Sistema de Cadastro Ambiental Rural, o Cadastro Ambiental Rural, estabelece normas de caráter geral aos Programas de Regularização Ambiental, de que trata a Lei no 12.651, de 25 de maio de 2012, e dá outras providências. Brasília-DF. Disponível: <http://www.planalto.gov.br/ccivil_03/_Ato2011-2014/2012/Decreto/D7830.htm>.

[Acessado em: 12 de Fev. 2018].

BRASIL. Decreto $N^{o} 23.793$ de 23 de Janeiro de 1934, Aprova o código florestal que com este baixa. Rio de janeiro-RJ. Disponível: $<$ http://www2.camara.leg.br/legin/fed/decret/1930-1939/decreto-23793-23-janeiro1934-498279-publicacaooriginal-78167-pe.html>. [Acessado em: 3 de Mar. 2018].

CARNEIRO, A. F. T. Cadastro imobiliário e registro de imóveis. Porto Alegre: Instituto de Registro Imobiliário do Brasil, 2003.

CNTA. Confederação Nacional dos Trabalhadores na Agricultura, Cadastro Ambiental Rural CAR: como se cadastrar. Brasília. Contag, 2014.

DINIZ, M. H. Sistema de Registros de Imóveis, São Paulo: Saraiva, 2012. 
EMBRAPA, Empresa Brasileira de Pesquisa Agropecuária. 2017. Código Florestal adequação ambiental da paisagem rural. Brasília. Disponível: $<$ https://www.embrapa.br/codigo-florestal/entenda-o-codigo-florestal/perguntas-erespostas $>$. [Acesso: 20 de set de 2017].

FERREIRA, A. B. H. Dicionário Aurélio Básico da Língua Portuguesa. Rio de Janeiro, 2010.

FONSECA L. C.; SILVA D. F.; CONPEDI-UFS, 2015. O Cadastro Ambiental Rural como direito à informação e o sigilo de dados. Revista Jurídica Unicuritiba, 2015, vol.4, $\mathrm{n}^{\circ}$ 41, p. 461-478. 〈http://revista.unicuritiba.edu.br/index.php/RevJur/article/view/1475/1008>. [Acessado em; 25 de Mai. 2018].

GIL, A. C. Como elaborar projetos e pesquisa, São Paulo: Atlas, 2008.

GUIMARÃES, V. T. A (in) constitucionalidade do Novo Código Florestal no STF e o voto de Luiz Fux. 2017. Revista Carta Capital [online]. Disponível: $<$ http://justificando.cartacapital.com.br/2017/12/05/inconstitucionalidade-do-novocodigo-florestal-no-stf-e-o-voto-de-luiz-fux>. [Acesso: 05 de Jan. de 2018].

INCRA. Instituto Nacional de Colonização da Reforma Agraria. 2017, Diretrizes estratégicas de implementação da reforma agrária/ Primeira Diretriz democratização do acesso à terra. Disponível em: <http://www.incra.gov.br/diretrizes-estrategicas > [Acesso: jan. de 2018].

ISA. Instituto Socioambiental, STF suspende julgamento do Código Florestal. 2018a Disponível: $\quad<$ https://www.socioambiental.org/pt-br/noticias-socioambientais/stfsuspende-julgamento-do-codigo-florestal-mas-prejuizo-para-meio-ambiente-ja-egrande>. [Acesso: fev. de 2018].

ISA. Instituto Socioambiental. Retrocesso ambiental consolidado, 2018b. Disponível: $<$ https://www.socioambiental.org/pt-br/blog/blog-do-isa/retrocesso-ambientalconsolidado>. [Acesso: mar. de 2018].

LASKOS, A. A.; CAZElla A. A.; REBOllaR, P. B. M. $O$ Sistema Nacional de Cadastro Rural: história, limitações atuais e perspectivas para a conservação ambiental e segurança fundiária. Revista Meio Ambiente e Desenvolvimento, 2016, vol. 36. Disponível: DOI: 10.5380/dma.v36i0.39124.

LOCH, C. et al. Landscape multifuncionality evaluation as a subsidy to public policies for sustainable rural development. Revista Ciência Rural [online], 2015, vol. 45. Disponível: 〈http://dx.doi.org/10.1590/0103-8478cr20131087〉.

LOCH, C.; ERBA, D. A. Cadastro Técnico Multifinalitário Rural e Urbano. Cambridge: Lincoln Institut of Land Policy, 2007.

MILARÉ, É. Direito do ambiente a gestão ambiental em foco. Revista dos Tribunais, 2011. 
MIRANDA, E. O STF e o Código Florestal. Jornal Digital Estadão, 2018. Disponível: <http://opiniao.estadao.com.br/noticias/geral,o-stf-e-o-codigo-florestal,70002191263>.

[Acesso: 20 de fev. de 2018].

MMA, Ministério do Maio Ambiente. Cartilha "CAR: Produzir com Respeito ao Meio Ambiente", 2016a. Disponível: <http://www.florestal.gov.br/publicacoes/503-cartilhacar-produzir-com-respeito-ao-meio-ambiente>. [Acesso: 24 de set.de 2017].

MMA, Ministério do meio Ambiente. Programa Piloto para a Proteção das Florestas Tropicais do Brasil, Brasília, 2017a. Disponível: <http://www.mma.gov.br/port/sca/ppg7/capa>. [Acesso: 2 jul. 2017].

MMA, Ministério do Meio Ambiente. Serviço Florestal brasileiro/ Quais são os Estados que utilizam a versão padrão do Módulo de Cadastro do SICAR, 2017b. Disponível: $<$ http://www.florestal.gov.br/o-que-e-o-car/61-car/167-perguntas-frequentescar\#car12>. [Acesso: 20 de jul. de 2017].

MMA. Ministério do meio Ambiente. Proteção das Florestas Tropicais/Programa piloto para a proteção das flores tropical do Brasil, 2009. Disponível: $<$ http://www.mma.gov.br/florestas/programa-para-a-prote\%C3\%A7\%C3\%A3o-dasflorestas-tropicais $>$. [Acesso 2 de jul.2017].

MMA. Ministério do Meio Ambiente. Cadastro Ambiental Rural - CAR (Cartilha Orientações Básicas), 2016b. Disponível: <http://www.florestal.gov.br/publicacoes/504-cadastro-ambiental-rural-car-orientacoesbasicas $>$. [Acesso: 10 de ago. de 2017].

MMA. Ministério do Meio Ambiente. Serviço Florestal brasileiro/ Módulo de cadastro, 2016c.

MMA. Ministério do Meio Ambiente. Etapas do CAR e Regularização Ambiental / Regularização Ambiental, 2017c. Disponível: $<$ http://www.florestal.gov.br/ifn?option=com_content\&view=article\&id=150: comissoes -regionais\&catid=49:informativos $>$. [Acesso: 15 de out. de 2017].

NELSON, J. STF prorroga votação do Código Florestal para a próxima quarta-feira. Revista Globo Rural [online], 2018. Disponível: $<$ https://revistagloborural.globo.com/Noticias/Politica/noticia/2018/02/stf-prorrogavotacao-do-codigo-florestal-para-proxima-quarta-feira.html >. [Acesso: 4 de mar. de 2018].

PIRES, L. R. G. M. Função social da propriedade urbana e plano diretor. Dissertação (Mestrado), São Paulo. PUC - SP, 2005. Disponível: <https://tede2.pucsp.br/handle/handle/6465>. [Acesso: 10 de mai de 2017]. 
POZZETTI, V. C. Direito do Estrangeiro, Imigrante ou Refugiado, á Propriedade Rural no Brasil. Revista Jurídica Unicuritiba, 2017, vol. 3, n 48, p. 482-503. Disponível: 〈http://revista.unicuritiba.edu.br/index.php/RevJur/article/view/2190/1370>. [Acesso: 18 out.2017].

QUEIROZ, L. E. J. Licenciamento ambiental e reserva legal no agronegócio brasileiro. Artigo eletrônico, 2011. Disponível: <https://jus.com.br/artigos/19149/licenciamentoambiental-e-reserva-legal-no-agronegocio-brasileiro/2>. [Acesso: 15 de maio de 2017].

SILVA D. C. O papel da regularização fundiária no Brasil: análise de um projeto de implementação de regularização na Vila Albertina em Campos do Jordão/SP. Dissertação (Mestrado), Univap. São José dos Campos. 2008. Disponível: <http://biblioteca.univap.br/dados/000002/00000256.pdf>. [Acesso: 10 de mai. 2017].

SILVA, D. F. O Cadastro Ambiental Rural (Car) Como Instrumento de Informação e Monitoramento da Reserva Legal no Estado do Pará. Dissertação (Mestrado), CESUPA. Belém-PA. 2015.2 Disponível: <http://www.cesupa.br/MestradoDireito/dissertacoes/Disserta\%C3\%A7\%C3\%A30\%20 -\%20Danielle\%20Fonseca\%20Silva.pdf>. [Acessado 26 jun.2017].

SOUZA, L. M. A Histórica Caminhada do Assentamento Padre Josimo I e II na Luta Pela Terra em Cristalandia-TO, Dissertação (Mestrado), UFT. Porto Nacional-TO, 2017.

Disponível: <http://repositorio.uft.edu.br/bitstream/11612/409/1/Lucin\%C3\%A9ia\%20Medrado\%20 de\%20Souza\%20-\%20Disserta\%C3\%A7\%C3\%A3o.pdf>. [Acessado em 20 de Out. 2017].

STF. Supremo Tribunal Federal. Relator profere voto no julgamento sobre novo Código Florestal, 2017a. Disponível: <http://www.stf.jus.br/portal/cms/verNoticiaDetalhe.asp?idConteudo=361342 $>$.

[Acesso: 5 de dez. de 2017].

STF. Supremo Tribunal Federal. STF inicia julgamento de ações sobre o novo Código Florestal. 2017b Disponível: $<$ http://www.stf.jus.br/portal/cms/verNoticiaDetalhe.asp?idConteudo=355704\&caixaBu

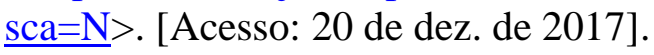

STF. Supremo Tribunal Federal. Ministros Luís Roberto Barroso, Rosa Weber e Dias Toffoli apresentam votos sobre Código Florestal, 2018a. Disponível: <http://portal.stf.jus.br/noticias/verNoticiaDetalhe.asp?idConteudo=370378>. [Acesso: 23 de fev. de 2018].

STF. Supremo Tribunal Federal. Ministros Ricardo Lewandowski e Gilmar Mendes votam no julgamento sobre Código Florestal, 2018b. Disponível: 〈http://www.stf.jus.br/portal/cms/verNoticiaDetalhe.asp?idConteudo=370391 >.

[Acesso: 26 de fev. de 2018].

STF. Supremo Tribunal Federal. Código Florestal: ministro Marco Aurélio e ministra Cármen Lúcia apresentam seus votos, 2018c. Disponível: 
$\langle$ http://www.stf.jus.br/portal/cms/verNoticiaDetalhe.asp?idConteudo=370270 $>$.

[Acesso: 26 de fev. 2018].

VIEIRA, V. A. As tipologias, Variações e Características da Pesquisa de Marketing. Revista FAE, 2002, vol.5, $\mathrm{n}^{\mathrm{o}} 1$ Curitiba, 2002, Disponível: <https://revistafae.fae.edu/revistafae/article/view/449/344> . [Acesso: 30 ago.2017].

ZAVADCKI, T. A. A tutela da posse na constituição e no Novo Código Civil. Revista Brasileira de Direito Constitucional, 2004, $\mathrm{n}^{\mathrm{o}}$ 5. Disponível: <http://bdjur.stj.jus.br/dspace/handle/2011/6723>. [Acesso 26 de jun. 2017].

\section{AGRADECIMENTOS}

A Comissão de Aperfeiçoamento de Pessoal do Nível Superior (CAPES), pela concessão da bolsa de Mestrado. Ao Coordenado do Setor de Geoprocessamento (SetGeo), o senhor Jancerlan Rocha, assim como as Coordenadoras da Coordenadoria de Controle Ambiental (CCA), as senhoras Leila D'Angela e Elisana Dantas, ambas Servidores da Superintendência de Administração do Meio Ambiente do Estado da Paraíba (SUDEMA), pelas informações prestadas.

(C) Copyright Ana Maria Ferreira Cosme, Janaína Barbosa da Silva y Revista GeoGraphos, 2019. Este artículo se distribuye bajo una Licencia Creative Commons Reconocimiento-NoComercial 4.0 Internacional.
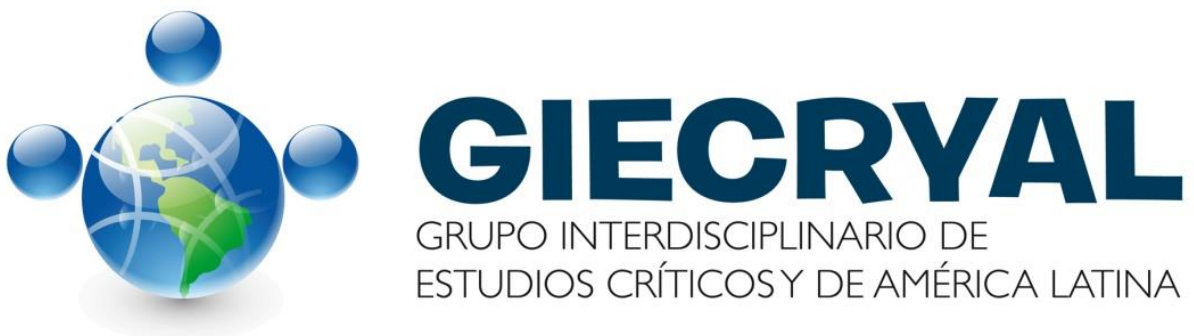

GRUPO INTERDISCIPLINARIO DE ESTUDIOS CRÍTICOSY DE AMÉRICA LATINA 